\title{
History, Exemplarity and Improvements: 18th Century Ideas about Man-Made Climate Change
}

\author{
By Anne Eriksen
}

\begin{abstract}
Can grain crops be increased? The issue was heatedly debated in 18th century Denmark-Norway, both for patriotic and economic reasons. The historian Gerhard Schøning (1722-80) answered affirmatively. Chopping down much of the forests that covered Norway would change the climate radically for the better. As a consequence of the warmer weather, the fertility of the soil would improve. Crops would increase, and new and even more delicate types of plants could be introduced. Schøning's argument was nearly entirely built on examples from Greek and Roman history, cited to demonstrate that since classical times, this kind of changes had already taken place in other parts of Europe.

Climate interested a number of $18^{\text {th }}$ century writers. It was not only a part of geotheory, but also included in theories about the history of society, law and culture as well as in medical thought. Ideas about a human-made climate change similar to Schøning's can be found in texts by e.g. Hume and Buffon.

The argument relied on a quantity of examples, as well as on the uncontested exemplarity of classical literature itself. Schøning's examples represent both series and ideals. The cases he cites are numerous (serial) instantiations of the same general mechanism: The effect of human interventions in nature. Yet at the same time they are models to follow, even if it will take some effort. Norway will never be as warm and fertile as southern countries, but Schøning exhorts his compatriots to "take courage and start!" History consisted of examples to learn from and models to follow.
\end{abstract}

Keywords: Gernhard Schøning; climate theory; examples; exemplarity; notions of history; 18the century.

Eriksen, Anne "History, Exemplarity and Improvements: 18th Century Ideas about Man-Made Climate Change", Culture Unbound, Volume 11, issue 3-4, 2019:

353-368. Published by Linköping University Electronic Press: http://www.cultureunbound.ep.liu.se 


\section{Introduction}

Can grain crops be increased? This was a heatedly debated issue in 18th century Denmark-Norway. The historian Gerhard Schøning (1722-80) answered affirmatively. Chopping down much of the forests that covered Norway, Schøning argued, would change the climate radically for the better. As a consequence of the warmer weather, the fertility of the soil would improve. Crops would increase, and new and even more delicate types of plants could be introduced.

The aim of this article is not to examine the validity of Schøning's argument, but to investigate his presentation of it. From where did he get his ideas about human-made climate change and its many advantages? What kind of empirical material did he invoke to support the claim? Examples and exemplarity stand at the core of Schøning's argument, and the article will investigate what types of example he chose, as well as the structure of the argument that they were employed to construct. Increasing crops and improving agricultural methods were important concerns in the period, debated among the authorities as well as by the general public. Successful improvements would increase food supplies and reduce the risk of famines, but were also related to leading economic theory. In physiocrat thought, agriculture represented a country's only real source of wealth and its potential for economic expansion. Improving agriculture meant to improve the state. As a public issue, contributing to this work, or at least to an enlightened debate about it, gained patriotic meaning as a way of performing 'public virtue' (Damsholt 2000:102). To citizens in the northern part of the Danish-Norwegian kingdom, the issue gained yet another layer of meaning. The debate over agriculture, soil and climate contributed to a more precise and detailed knowledge about Norwegian topography and the natural conditions of the country. In this way, the significant differences between the landscape in rocky and mountainous Norway versus the flat and fertile Denmark did not only carry agricultural and economic meaning, but did also become symbols of a national character. From this emerged a specific kind of "patriotic nationalism", emphasizing national particularities within the frames of the composite state and its absolute reign (Storsveen 1997:18).

This was also the backdrop for Schøning' small work Velmeente Tanker om Agerdørkningens muelige Forbedring i Norge, published in 1758 ('Well intended thoughts on the possible improvement of grain cultivation in Norway', hereafter VTA). In the preface, Schøning presented his book, a mere 70 pages, as one of the several "minor texts" recently published on the issue in the kingdom of Denmark-Norway. Differing from the majority of the authors, however, Schøning wanted to write particularly about Norway. Motivated by his "sincere love for his fatherland and honest wish to serve it when possible" (Schøning 1758: a3), he offered his thoughts on agricultural improvement to the reading public.

Schøning had been living in Trondheim since 1751, engaged as Rector 
of the cathedral school. In his spare time he studied history, and became well known for his erudition. Together with his good friend Peter Friederich Suhm, who had moved with him to Trondheim, Schøning worked with old Norse history and geography. The two friends met twice a week to solve the "deep mysteries" of ancient Nordic history, Schøning specializing in the Norwegian and Suhm in the Danish parts of it (Suhm 1781:b). The book Forbedringer til den gamle danske og norske Historie ("Improvements to the ancient Danish and Norwegian history") published in 1757, was the fruit of this joint venture. The year after, their work took a new turn when the newly appointed bishop, Johan Ernst Gunnerus, arrived in Trondheim and invited the two friends into a new project. Together the three of them grounded what is still known as The Royal Norwegian Society of Science and Letters. Natural history was Gunnerus' own prime interest, and it gained a dominant position in the new society's work, even if history and literature also were cultivated (Brenna 2009). Important methodological points of contact existed between antiquarian and natural history (Eriksen 2007), and may have been the background for the antiquarian turn in Schøning's work the following years. Likewise, the newly established society and its ambition to be useful is what inspired him to make use of his historical knowledge to contribute to agricultural improvements (Suhm 1981:b2).

\section{The Authority of Ancient History}

Schøning's analysis and argument concerning agriculture and, more precisely, grain crops in Norway, is nearly entirely built on quotes and examples from classical literature, mainly Greek and Roman history. Manufactures, arts and trade in Norway are far more easily improved than agriculture, Schøning starts his text. For what can be achieved in a country situated so far north, so filled with large mountains and with such a cold climate? Most people, Norwegians as well as foreigners, would hold it impossible "to sow and reap from hard stone", and claim that a country so far north would never be able to support its population unless it could be moved further south, or some of the pre-historic giants be re-introduced to move away the rocks (Schøning 1758:8f). It is as a contrast to this adynaton, or symbol of paradoxical impossibility, that Schøning presents his own bid: By means of examples from classical texts, he will show that what others hold for impossible, not only can be achieved, but actually has already been so in a majority of European countries.

He starts with Tacitus. In Germania, from 98 C.E., Tacitus described the land and customs of the native tribes of Germany. They must be indigenous people, for no man from Italy, Asia or Africa would settle in "such an ugly land, where the air is so sharp, the soil so sadly uncultivated and everything looking so dreary, if it was 
not his own fatherland" (Schøning 1758:10). Tacitus also says, according to Schøning, that even if the soil in Germany is not exclusively bad, the land is everywhere covered with large forests or hideous thickets and marshes. Cattle are small and poor, and the inhabitants do nothing but eat and sleep. They live in caves or huts, and wear animals' hides rather than proper clothes (Schøning 1758:10ff). Is this not rather like Norway and Sweden? Schøning asks. And Tacitus is not alone, he underscores. Other authors from the same period tell similar stories. Pomponius Mela and Cæsar also tell that the German tribes are nomads, they live from milk, cheese and meat, do not grow any crops and have no permanent abodes. Strabo and Seneca both say that Germany is a land of never-ending winters, bad weather and infertile soil (Schøning 1758:12ff).

So, after what has so far been said, Schøning writes, he hopes that every reader who confides in his words will have seen that Germany "in the most ancient times", was not a bit better than the poorest parts of Norway or Sweden today (Schøning 1758:16). From this, he goes on to state a rule in accordance "with nature itself as well as with experience":

The less a country is inhabited, and the more it is overgrown with forests and covered with swamps and marshland, all of which usually accompany each other, the less will the sun be able to do its work, and the more will the air be saturated with thick vapours, the colder, more unpleasant and unstable the weather and, consequently, the soil will be less fertile, independent on the country's location on the globe. (Schøning 1758:16)

More examples support the claim, taken from the same type of sources, but applied to other tribes and countries. Ancient Gaul knew neither wine nor grain, and according to Titus Livius this was the reason why Gallic tribes crossed the Alps and settled in northern Italy: They wanted access to the wine. Even earlier, however, the situation was equally poor in both Italy and Greece. According to Diodoros Siculus, the Ligurians lived from meat and water, while the inhabitants of Corsica, Sardinia and Sicily nourished themselves on honey, milk and meat. Thycidid tells that some tribes in Greece ate raw meat.

So how did these ancient people learn to cultivate the soil, to plough, sow and reap? The Egyptians, the Sicilians and the Cretes all have claimed being the first inventors of these arts, according to Diodoros Siculus. Schøning believes the honour to go to the Egyptians, even if they too are reported to have eaten grass and wild plants and dressing in hides in the earliest times (Schøning 1758:21). From this new round of "rather elaborate" examples, Schøning can formulate a second rule. It is structured in three parts, which makes it resemble a syllogism. 
First, no land, in and of itself, is capable of producing wealth, unless assisted by human efforts, Second, with diligence and good arrangements over time, other countries now abound in agricultural produce, sufficient for themselves and for export, despite being considered to be unfit for agriculture in ancient times due to their forests, mountains and bad climate. And third, as agriculture already has wandered the long distance from its birthplace in Egypt and now exists even in the north, only some final improvements are needed to finalize the process and make the northern countries fully take part in it. Schøning concludes with a maxim:

The numerous cases supply clear examples that things which originally have occurred only in the most remote and warmest countries, and which have been imagined to be possible in no other places, have been fully elaborated over time, and reached almost to the farthest north. (Schøning 1758:25f)

He adds some final examples: Silk worms were brought from China to Europe in the time of Justinian. Wine produced in the once so uninhabitable northern Germany is now reckoned among the best, and cherries, which reached Italy only at the time of the birth of Christ, are now grown even in the northern parts of Norway (Schøning 1758:27).

Schøning's text may be read as a story of progress or development, taking place over time. It presents a narrative of humankind that still is recognized: The transition from hunters and gatherers to peasants. However, words like development or progress never occur in Schøning's text. His terms are improved, take place, be capable of, bring into being, produce, as well as goods, efforts, wealth, orderings and arrangements. And most importantly, the cases that he cites are explicitly named examples. I will argue that this is a significant clue to Schøning's way of constructing his text.

\section{Tacitus, for example}

According to literary scholar John D.Lyons, an example is "a connection between a general statement or maxim and local or specific actualization of that maxim" (Lyons 1989:x). By means of examples, the truth of the general phrase or maxim is embedded in specific and local instantiations, which makes it easier to grasp, understand and believe in. Conversely, turning the specific case into an example of something more general makes it reach beyond itself and its immediate context. It exemplifies the class to which it belongs, and this identity, rather than the uniqueness of the specific case, is what defines it. Lyons is emphatic that "examples do not happen, they are made", and investigates the methods and strategies that are 
employed in the production of examples. Iterativity, exteriority and discontinuity are among them: A number of related examples will often be given to reiterate the same maxim, as was the case with Schøning's enumeration of more or less similar statements from a variety of authors. As rhetoric devices examples point to seemingly naturally occurring phenomena that are external to speech itself. Even if they never supply final proofs of anything, this exteriority makes examples convincing because they seem to exist independent and outside of linguistic representation. They refer to things that "just are there". However, to work well, examples have to be carefully chosen and pruned. Only when made discontinuous with their original setting, they can stand forth as examples to illuminate and learn from. These example-making strategies can all be easily identified in Schøning's text. He has been mining classical texts for phrases and passages that describe land, food, housing and (lack of) agriculture among a number of peoples and tribes, and made them discontinuous with their context. He has chosen and cured the excerpts, and composed his own argument by relating them to each other. Admittedly, in Schøning's case the examples do not come from an extra-linguistic empirical world, "out there", but from other texts. These texts, however, the classics, carried strong and unquestioned authority as sources of truth.

But what kind of truth? What is the message of the examples? Literary scholar Alexander Gelley has pointed out that examples may rest on two very different rationalities. He calls them Platonic and Aristotelian respectively. According to the first, the example represents an ideal that will never be achieved, but which nonetheless is paradigmatic. The example will thus be used as a model. The second, on the other hand, sees the example as one instantiation of a more general class. From this perspective, the example is defined through seriality, and the category to which it belongs is more important than its uniqueness (Gelley 1995). Gelleys analysis is illuminating, but conceals the very important fact that the two principles he describes most often get entangled and the difference between them blurred. Rather than being either "Platonic" or "Aristotelian", examples most often are both unique models and recognizable cases, and this is what makes them rhetorically so effective. Even when presented as mere illustrations of something more general, examples are also given a paradigmatic meaning (Eriksen et al 2012:12f). The example is both one of a series and one of a kind, and it is in this doubleness that its power resides. Functionally, the example is a point of exchange between the regular and the exceptional, and from this stems its cultural and rhetorical energy.

Schøning's text is based on this logic. His argument becomes convincing because the examples are numerous and taken from different contexts. The lack of agriculture in Germany for instance (!), is not merely based on Tacitus, but also on several other authors. This quantity of testimonials is vital, and Schøning even seems to find it difficult to stop giving examples after having presented the rules 
or maxims that they illustrate. Seriality bolsters his argument. At the same time, however, his selection of texts comes not only from the lack of other historical sources, but has much to do with the authority that just these texts carried, with the uncontested exemplarity of classical literature.

History, to Schøning and his contemporaries, was not a research discipline that unearthed and critically investigated primary sources. Material evidence and physical traces were dear to antiquaries in the period, but had little impact on history. In Schøning's own work, these two traditions of knowledge were largely held separate (Eriksen 2007). Working with history very much consisted of reading and rereading well-known ancient texts, compiling, commenting, comparing and collating. The work was far from uncritical, but the energy largely spent on analyzing intertextual relations. History was a literal pursuit, which made style and rhetoric important considerations. Moreover, the evaluation of historical truth did not only concern the "wie es eigentlich gewesen" that became the credo of the new historical research from the $19^{\text {th }}$ century, but the order and general probability of events, the honour and honesty of ancient authors, and the political, military or ethical insights that could be extracted. Cicero's definition of history as magistra vitae - "the teacher of life" - was frequently evoked, and worked both as a general saying and as a starting point for historical analysis (Koselleck 1985:23ff). History consisted of examples to learn from and models to follow. This was also the reason why reading history was an important part of the education of princes. History gave examples of political and military victories and losses, and told about the personality, virtues - and vices - of former kings, generals and statesmen. By way of example, it gave advice and taught useful lessons in strategy, politics and statesmanship. Within these frames, the classical authors held a kind of double exemplarity as models. Not only did they tell about persons, events and institutions from the Greek and Roman world that still was a European norm and model, they also represented highly admired rhetoric, literary and linguistic ideals. As such they were followed and imitated by later history writers. Schøning himself is known to have modelled his style on Polybius (Suhm 1781:b5).

Schøning's examples in VTA thus represent both series and ideals. The cases he cites are numerous (serial) instantiations of the same general mechanism: The effect of human interventions in nature. Yet they are also models to follow, even if it will take some effort. Norway will never be as warm and fertile as southern countries, but Schøning exhorts his compatriots to "take courage and start!" (Schøning 1758:23). We should at least try to follow the example of others (Schøning 1758:28). Ideals are not easy to reach, but we should nonetheless strive for them. 


\section{Climate, Determinism and Improvements}

The changes that Schøning describes, or rather quotes from the classical authors, concern human cultivation - from hides and caverns to proper clothing, fixed abodes, houses and villages. This is accompanied by a cultivation of nature, from wild plants and animals to agriculture and domesticated cattle. These important improvements are nonetheless only the secondary effects of the change that is the core of Schøning's argument: The human-made climate change. His first and most fundamental "rule" (above) states this. Human efforts will not only change forests into fields and turn marshes and swamps into inhabitable areas, fit for peasant villages and cattle pasture. It will also chase the excessive snow, rain and fog that reign in uncultivated and uninhabited regions. The climate will become milder and more temperate, the sun will shine, and due to this, the soil will be more fertile. Not only grain, but even more tender plants will be grown. What his numerous historic examples most fundamentally demonstrate is therefore not the development of human tribes from a stage of hunting and gathering to that of agriculture, but a general law of nature: Human endeavour can and will impact climate and change living conditions on earth. The argument, or rather statement, is presented in three numbered points: 1) It is not the case that cold winters prevent a land from being fertile, because the examples have shown that even southern countries had hard winters in ancient times. 2) Neither is a country's cold climate and lack of fertility caused by its northern situation or high altitude, but:

3) The more the land is cultivated, and the more populous it gets, the more the frost will decrease and the milder becomes its climate, so that at among two countries on the same altitude, there will always be a milder air and less frost in the one that is the most cultivated and inhabited than in the other, which in itself as just as good or better, but not so well cultivated (Schøning 1758:35).

These ideas were not original to Schøning. In their preface to the recent English translation of French naturalist Georges-Louis LeClerc Buffon's Les époques de la nature, originally published in 1778, Jan Zalasiewicz et al present this French naturalist as a pioneer of a notion of the anthropocene (Zalasiewicz et al 2018:xviff). Their reason is that in the last of the seven epoch that consisted the earth's history, according to Buffon, human interventions have changed the climate of the globe and made it warmer. In Buffon's view, this man-made warming counter-acted the globe's natural process of cooling, and made the earth inhabitable and cultivable. Les époques de la nature was originally conceived as a part of the introduction to Buffon's monumental and hugely influential work Histoire naturelle, which was published in 36 volumes between 1749 and 1789. As an independent work it be- 
came an influential contribution to the field of earth history by describing a directional development of the globe, into which man entered only in the very last epoch. Its contents were nonetheless not particularly original, but drew on a legacy of geotheorizing reaching back to Aristotle (Rudwick 2005:140). The description of the seventh and anthropocene-like epoch was added to the work while it was already in press, Martin Rudwick points out. It had the effect of "emphasizing unambiguously the pre-human character of the earth of all the preceding epochs. To formulate the theory that "the whole of human history was confined to the most recent portion of a far longer temporal sequence", Buffon nonetheless sought recourse to a rather widespread idea (Rudwick 2005:146). The examples that Buffon cites to support his theory are largely the same as those in Schøning: Tacitus, Cæsar, Polybius and Strabo. Classical history plays the same role in Buffon's history of the earth as in Schøning's treatise on grain crops in Norway.

Climate was an issue that interested number of $18^{\text {th }}$ century writers and thinkers in a number of different ways. It was not only a part of geotheory, but also included in theories about the history of society, law and culture as well as in medical thought. Rather than looking for their first and most original articulations, it might be fruitful to investigate the different ways ideas about climate were used, how they were adapted and modified, and what arguments and theories that they were employed to construct in the $18^{\text {th }}$ century. Two main approaches dominate. Climate could be seen as a determining factor, impacting nearly everything from individual health to social institutions, and consequently explaining differences between states or societies. Montesquieu and his l'Esprit des lois (1748) is probably the best-known example of this type of climate theory today, but was far from unique in its own time (Berry 1974, Hulme 2011). While this perspective saw man as determined by climate, the opposite stance also was held: Climate as determined or at least shaped, by man. While only the second of these two approaches is relevant to earth history and geotheory, both perspectives can be found, often interrelated, in $18^{\text {th }}$ century social theory, or, as in Schøning, in works on changes and improvements. In these cases, the idea is that man and society is determined by climate, but also that man can change both himself and his country by influencing the climate. Even if climate is important to shape both society and nature according to these theories, it is not determining in the more simplistic sense described by Mike Hulme (Hulme 2001). Moreover, to Schøning and his contemporaries, the climate issue was part of a typical Enlightenment discourse about improvements - natural as well as political - and the possibility of man to influence and shape his own conditions of life.

An influential work in this line was Jean-Baptiste Du Bos' Réflexions critiques sur la poësi et sur la peinture (1719). Du Bos had a reputation as a French diplomat and a historian of the French monarchy and state system. In 1720, his recent work 
on aesthetic theory also earned him a seat in the Académie Francaise, and he was the permanent secretary of this institution from 1722 to his death in 1742. Du Bos argued that the great historical variation in artistic creativity must be due to changes in climate over time and between countries. In this he was a determinist, but he also saw the possibility that human efforts would change the climate, and thus improve the arts. This was also what he expected would happen in America, when colonization had turned the continent into cultivated land (Fleming 1998:14). Du Bos was one of the inspirations for Montesquieu's climate determinism, but also for David Hume, who developed the other and more flexible aspect of the ideas. In his essay On the Populousness of Ancient Nations, from about 1750, Hume argued for man-made climate change. Du Bos had pointed out that the climate in Europe had changed and become milder since classical times, and what could explain this apart from the consequences of increased cultivation, Hume asked?

\begin{abstract}
Allowing, therefore, this remark [of Du Bos] to be just, that Europe is become warmer than formerly; how can we account for it ? Plainly by no other method than by supposing, that the land is at present much better cultivated, and that the woods are cleared, which formerly threw a shade upon the earth, and kept the rays of the sun from penetrating to it. (Hume 1826:496)
\end{abstract}

He also shared Du Bos' expectations concerning America:

Our northern colonies in America become more temperate in proportion as the woods are felled; but, in general, every one may remark, that cold is still muck more severely felt, both in North and South America, than in places under the same latitude in Europe. (Hume 1826: 497)

The entanglement between determinism and improvement is demonstrated in James R. Fleming's overview of Enlightenment argument on "climate change, culture and cultivation". To the idea that climate determines or at least shapes culture was added an understanding that the climate in Europe had moderated since ancient times. The cause of this was held to be gradual clearing of the forest and subsequent cultivation. A parallel development could be observed in America at the time, these changes were caused by settlement. Consequently, America would gradually turn more fit for European-type civilization, and less for native cultures (Fleming 1998:18). The general debate gradually turned more particularly to the potentialities of the new American land. Fleming's sample list of authors who supported the idea that America would be improved by man-made climate change, starts with William Wood in 1634, in his work New England's Prospect, and ends 
with Metorologische Untersuchungen by Heinrich Wilhelm Dove in 1837 (Fleming 1998:32). In the course of these two hundred years, human-made climate change was an integral part of debates over culture, cultivation, politics and society.

\section{Clear, Drain, and Till!}

If we want Norway to become more fertile, Schøning wrote, we must "cut down the forests, drain the thickets and marshlands, and clear the land" (Schøning 1758:39). He nonetheless also underscores that the more simply and "naturally" innovations are introduced, the more successful will they be. Consequently, the clearing work should start with forests that are very large and not of practical use for anybody. The mines need firewood and charcoal, Schøning points out, and the woods that produce it, are deemed "useful" and should be saved. But forests that consist largely of small trees, bushes and thickets ought to be cleared, particularly if the land they cover is flat and located close to the already cultivated fields. The forests near the farms are often used for pasture, but Schøning argues that they are anyhow too poor to give the cattle much to eat and ought to be put to better use. Peasants in other countries feed their cattle on far more restricted areas, so this should be possible even in Norway. He has also noted that in the deep Norwegian valleys, farms tend to be situated rather high up from the river, which leaves wide areas of land along the banks, hardly used for anything but occasional pasture. This is due to the seasonal floods, but Schøning also sees peasant tradition and conservatism as part of the cause. The "forefathers" built the farms in the hillside, and nobody has since thought of changing the ancient patterns of habitation. Draining the river banks may produce good and fertile new fields in these flat areas, according to Schøning (Schøning 1758:44). Draining marshes in the forests will also give an effect, even if the soil in these cases often is barren. Getting rid of the icing water that the marshes contain, will nonetheless prevent it from flooding nearby fields and harming the crops there. The same applies to the "cold vapours" that the marshes emit. Moreover, the drained marshes will produce peat that can be used for fuel instead of wood.

Compared to his detailled knowledge about classical history, Schøning demonstrates only superficial insight in the agricultural systems of his time, and a rather limited understanding of their functionality. More important in the present context, however, is it that this part of Schøning's text is almost completely devoid of examples. His advice concerning the work to be done to clear the forests and drain the land is given in generic terms. He cites no specific cases of work that has been done or efforts made. Neither literature nor more current events is evoked to substantiate the argument. The title of the work makes it rational to expect the historical examples that have been cited so far to form the basis for 
proposed improvements in the present, but the section containing these pieces of advice is short and not very detailled. And rather quickly, Schøning returns to history, and to examples. Has agriculture in Norway improved since ancient times? he asks (Schøning 1758:50). After all, grain has long been grown in Norway, and according to the theory presented in the previous parts of the work, even this northern country should be thought to have taken part in the general process of slow climate change. And, Schøning admits, it may seem so, at least when one considers gardening, vegetables, flowers and other "small ornaments" (Schøning 1758:50). But if one looks at the two more important segments of farming, that is grain crops and livestock breeding, the picture will change, and the histories tell us that in most parts of the country, they were as good or better in ancient times. From the sagas of Snorre he picks the information that grain was grown in the northernmost regions of the country as early as in the time of Harald Fairhair (9th century). The island of Senja was self-supplied with grains in the time of St.Olav (11th century), and the local chief able to give several large banquets during the winter. And as an example of veritable abundance, Schøning refers to the archbishop Eystein of Nidaros, who during the $12^{\text {th }}$ century obtained a royal privilege of exporting surplus grain to Iceland (Schøning 1758:53). Again, these examples combine seriality and uniqueness in Schøning's argument. They are presented as instantiations of how things "normally" were in ancient Norway, with grain grown in abundance nearly all over the country. At the same time, they also represent extreme and unique cases, claiming that grain could be grown even in the northernmost parts of the country and demonstrating the quite extraordinary wealth of the medieval archbishopric.

\section{Unruly Examples}

Do not these historical examples make Schøning argue against himself? Have not the examples in the first part of the work demonstrated that climate and cultivation gradually has improved in Europe since ancient times? With such rhetorical questions does Schøning start the last section of his text, where he explains more in detail why agriculture actually has decreased in Norway (Schøning 1758:53f). Once again he returns to historical issues. This time they are not cited as examples, however, but as significant events and subsequent structural changes. He starts with the $14^{\text {th }}$ century plague, the Black Death, which left large parts of the country uninhabited and uncultivated. The remaining population sought to the coastal regions. They lived from fisheries, and bought the grain that they needed from the German Hansa merchants. The forests in the coastal areas were rapidly brought down and sold as timber, bringing ready money that made it possible to buy the foreign goods. In the inland regions, mining had the same effect of deforestation. 
Producing and transporting charcoal and wood for the works gave the peasants money for the taxes and for seed corn (Schøning 1758:56f). Schøning does not agree that working at the mines makes the farmers neglect agriculture and the tending of the soil. These two types of work will not interfere with each other because the take place in different seasons. Moreover, bringing down the forests has already produced new fields and settlements.

The argument indicates that Schøning sees agriculture as the primary occupation and way of life, historically as well as normatively. Fisheries, on the other hand, are both more recent and less ideal. This fits well with physiocrat economic thought, but also with Schøning's own ideas about ancient Norwegian history. As an historian, Schøning was deeply interested in the old Norse kingdom, its powerful chieftains and kings. The saga literature, which made up his main source material, bore witness to an expansive and well-developed maritime culture. The term "Viking" did nonetheless mean pirate or robber to Schøning and his contemporaries, and was not invested with more national and cultural values until the $19^{\text {th }}$ century (Eriksen 2007: 105f). Consequently, the peasants that populated it were largely interpreted in terms of territory, and implicitly of its cultivation and the wealth of ancient lords. It is this presumed agricultural society that is put forward as the paradigmatic example to follow in the present.

Turning to the present, Schøning also identifies two other important reasons for the relative decline of agriculture in Norway. The real problem is not historical events, he claims, but challenges in the present. The population is simply too small, and the lack of people "prevents the advancement and growth of several useful institutions and arrangements" (Schøning 1758: 59). Emigration depopulates the kingdom, mainly due to the "thousands" of persons who annually entered into Dutch maritime service. This draining of the work force made it difficult to run the farms in Norway (Schøning 1758: 60f). The commons represented another problem. Schøning argued that the fact the many forests in Norway were common land, also was the reason why they were badly kept and often became over-exploited. Moreover, the common ownership also prevented industrious individuals from clearing the land and cultivating it (Schøning 1758: 61ff). Schøning was neither the only nor the first to identify these two problems, they were both much debated in the period. The fear of depopulation was common in Europe. It reflected the physiocrat belief in agriculture as the only real source of wealth, and the consequent need for agricultural labour. As pointed out by Foucault and others, the population came to be considered as a resource to be managed by the state. In the same period, new tools to do this were developed, on the form of censuses and registers of different kinds (Foucault 2009, Rusnock 2002).

Despite these nods to current debates and issues, showing that he is informed about them, Schøning comes close to answering his own rhetorical questions in 
the affirmative: There is a certain inconsistence in his argument, concerning the development of agriculture in Norway since "ancient" times as well as in his advice for improving both soil and climate. One reason may be a lack of knowledge. Schøning seems remarkably ignorant of the fact that Norway already had been the object of a rather dramatic deforestation, which started in the late $17^{\text {th }}$ century and reached a peak in his own time. Coastal areas in the western parts of the country had long been bared, and in the $18^{\text {th }}$ century a general overtaxation of the forests became an issue. In the present context, it is nonetheless more relevant to relate the inconsistencies of Schøning's text to example theory.

John D. Lyons underscores that two important features of examples are what he calls their undecidability and their excess. Examples are open-ended, and will never supply final proof for anything. Seriality is intended to compensate for this, but one single counter-example will always be sufficient to destroy the argument. As models for future action, on the other hand, examples are based on a supposition that "similarity will prevail over difference". The risk implied is that the gap "between prediction and occurrence" becomes too wide (Lyons 1989:33). This intrinsic undecidability is further enhanced by the example's surplus of meaning. "Any element of historical reality or even any fiction adduced to support a generalization will have characteristics that exceed what can be covered by the generalization," Lyons point out (Lyons 1989:34). If the example did not say anything more than the maxim that it is intended to exemplify, it would be a mere reiteration of the general statement. Surplus information is needed, but at the same time it makes the example ambiguous. Examples are always "unruly" (Gelley 1995): They may be turned and twisted, interpreted and integrated in new setting were they are ascribed new meanings. In consequence, they may end up as examples of something very different or even contrary to the maxim that they initially were intended to illuminate. Lyons points out that the more the example is elaborated into a story, "the narrative begins to threaten the control of the generalization" (Lyons 1989:34). If the example is not made sufficient discontinuous from its original contexts, the same will happen: The richness of the example opens up a space of interpretation that is not controlled by the author. This is also what seems to happen in the latter parts of Schøning's text. The examples escape control and become undecidable and ambiguous.

Even if deforestation in Norway was becoming an acknowledged problem in the period, Schøning could have chosen to use it as an argument for his climate change theory. From his own argument in the first part of the text, it might easily be assumed that the deforestation of the coastal areas of Norway would cause the same type of desirable climate change as that which formerly had taken place in southern Europe. It could thus be seen as the very beginning of the efforts that Schøning so strongly advocates. But this is not the case. Instead, the baring of the 
coastal areas and export of timber become elements in another story. Schøning describes a continuous historical change from the presumed rich agriculture in ancient Norway to its more deplorable present state. The examples he cites are no longer models, but illustrate successive stages in this development. As such, they cannot be made discontinuous with their historical context. On the contrary, the connection between the examples and the larger process they are part of has to be maintained and underscored in terms of causality. As a consequence, the examples' undecidability and excess of meaning increase, and the examples themselves becomes unruly. It complicates the matter further that the deforestation in Norway, as Schøning recounts the story, was not related to agriculture and its improvement, but rather to the contrary: The cessation of agriculture and the transition to an inferior way of life based on fisheries, trade and ready money. The various stages and single events of this process could hardly be presented as models to follow. Within these frames, the clearing of the forests no longer represented improvements or ideals. When done for commercial reasons and in the context of agriculture in decline, its meaning is changed and its exemplarity wanes.

It may be objected that Schøning's ideas about a rich ancient agriculture is purely conjectural and that his knowledge about the present state of the forests in Norway is rather scarse. What makes the two parts of his text so different from each other is nonetheless not a lack of information, but the fact that they reflect two different narrative structures. The specific cases - or examples - serve different aims in these structures. The examples from classical literature, cited in the first sections of the text, are presented as specific, individual instantiations of a general change. This change is the maxim that the examples illustrate. It is historical, in the sense that it has taken place in the past, but also in the sense of representing a general rule or law whose validity is independent of time and specific circumstance. In this setting, the examples can easily combine seriality with the ideal. The examples in the second part, on their hand, are not employed to illustrate a maxim, but a process. They represent open-ended, gradual historical change. As such, the examples may illustrate serial events, things that have taken place more than once, like the deforestation of the coastal areas. But they cannot be made discontinuous with the process, and their ambiguity not very much reduced. In this position the examples cannot work as models, but remain open for reinterpretations and other unruly behaviour.

Anne Eriksen is a professor of cultural history. Her research interests include heritage and museum studies, collective memory, notions of history and temporality and the history of climate. Among her publications are Musem. En kulturhistorie (Pax publishers 2009) From Antiquities to Heritage (Berghahn Books 2014) and "Copies, Concepts and Time" (Culture Unbound, vol. 9, no. 1 2017). E-mail: anne.eriksen@ikos.uio.no 


\section{References:}

Berry, Christopher 1974: "'Climate' in the Eighteenth Century. James Dunbar and the Scottish Case", Texas Studies in Literature and Language 281-292.

Brenna, Brita et al 2009: Aemula Lauri. The Royal Norwegian Society of Sciences and Letters, 1760-2010, Sagamore Beach, Mass. Science History Publications.

Buffon, Georges-Louis Leclerc 2018 [1778]: The Epochs of Nature. Chicago, University of Chicago Press.

Damsholt, Tine 2000: Faedrelandskcerlighed og borgerdyd. København, Museum Tusculanum Press.

Du Bos, Jean-Baptiste 1719: Réflexions critiques sur la poësi et sur la peinture. PJ.Mariette, Paris.

Fleming, James Rodger 1998: Historical Perspectives on Climate Change. New York, Oxford university Press.

Eriksen, Anne 2007: Topografenes verden. Fornminner og fortidsforståelse. Oslo, Pax forlag.

Eriksen, Anne, Ellen Krefting og Anne Birgitte Rønning 2012 (red): Eksemplets makt.Kjønn, representasjon og autoritet fra antikken til i dag. Oslo, Spartacus.

Foucault, Michel. 2009. Security, Territory, Population: Lectures at the Collège de France 1977-1978. New York: Picador.

Gelley, Alexander 1995: Unruly Examples. On the Rhetoric of Exemplarity. Stanford, California, University of Stanford Press.

Hulme, Mike 2011: "Reducing the Future to Climate. A Story of Climate Determinism and Reductionism". Osiris vol. 26, no 1, pp.245-266.

Hume, David 1826 [1745]: The Philosophical Works, vol. 3, Edinburgh, Black \& Tait.

Koselleck, Reinhardt 1985: Futures Past. On the Semantics of historical Time. MIT Press.

Lyons, John D. 1989: Exemplum. The Rhetoric of Examples in Early Modern France and Italy. Princeton, N.J., Princeton University Press.

Rudwick, Martin J.S. 2005: Bursting the Limits of Time. The Reconstruction of Geohistory in the Age of Revolution. Chicago, University of Chicago Press.

Rusnock, Andrea A. 2002. Vital Accounts: Quantifying Health and Population in Eighteenth-Century England and France. Cambridge: Cambridge University Press.

Schøning, Gerhard 1758: Velmeente Tanker om Agerdørkningens muelige Forbedring i Norge. København, Møller.

Storsveen, Odd Arvid 1997: "'Fornuftig Kierlighed til Fædrenelandet'. En analyse av norsk patriotisme mellom 1784 og 1801." I: Storsveen, O.A. (red.): Norsk patriotisme før $1814=$ KULTs skriftserie nr 88. Oslo, Norges Forskningsråd.

Suhm , P.F.1781: "Fortale". I: G.Schøning, Norges Riges Historie, bd. 3, København, Gyldendal.

Zalasiewicz, Jan, Anne-Sophie Milon and Mateusz Zalasiewicz 2018: Introduction. In: Zalasiewicz, Jan et al (eds.): The Epochs of Nature. Chicago, University of Chicago Press. 